\title{
刈り取り後におけるニラの器官別の重量ならびに糖類含量の変化
}

\author{
安 東赫 ${ }^{1 *}$ ・池田英男 ${ }^{2}$ \\ ${ }^{1}$ 茨城県農業総合センター園芸研究所 319-0292 笠間市安居 3165-1 \\ 2 大阪府立大学大学院生命環境科学研究科 599-8531 大阪府堺市学園町 1-1
}

\section{Changes of the Weight and Sugar Contents in Chinese Chive Organs after Cutting}

\author{
Ahn, Dong-Hyuk ${ }^{1 *}$ and Hideo Ikeda ${ }^{2}$ \\ ${ }^{1}$ Ibaraki Agricultural Center, Horticultural Institute, Kasama, Ibaraki 319-0292 \\ ${ }^{2}$ Graduate School of Life and Environmental Sciences, Osaka Prefecture University, Sakai, Osaka 599-8531
}

\begin{abstract}
To examine re-growth and distribution of carbohydrates, this study measured the dry weight of leaves, bulbs, basal stem and roots, and the sugar concentration in each organ of Chinese chives (Allium tuberosum Rottler) grown by sand culture for 20 days after harvesting. The total dry weight first decreased for 12 days after cutting, followed by an increase. Nevertheless, the total dry weight recovered to only about $80 \%$ of its initial weight, when the leaf length became harvest size ( $40 \mathrm{~cm}$ and over) on the twentieth day after cutting. Especially, after the initial decrease, the dry weight of the root only reached about $50 \%$ of its initial weight. This finding indicated that the Chinese chive root plays a significant role as the carbohydrate storage organ. A high degree of fructose was demonstrated in the leaf, whereas sucrose was dominant in other organs (bulb, basal stem and root), showing the highest concentration in the basal stem. However, the great decrease in concentration of sucrose in each organ was shown from the fourth day after cutting. Total sugar contents within alcohol soluble solids of the plant were lowest on the fourth day after cutting, then, increased with re-growth of the leaf, and consequently, 20 days after cutting, exceeded the initial sugar content of the plant. During the examination it was also discovered that the total carbohydrate (saccharide) content declined to the minimum level $(60 \%$ of the initial level) on the eighth day after cutting. A partial recovery up to $72 \%$ followed in the remaining 20 day period. The main cause of this is related to the content of polysaccharides, which increased only slightly after a significant decrease during the initial eight days after cutting.
\end{abstract}

Key Words : Allium tuberosum Rottler, regrowth, sugar, translocation

キーワード : ニラ, 再生, 転流, 糖

\section{緒 言}

ニラは地上部のみを収穫物とする野菜で，一般には収穫 後に残った地下部から再生した新しい葉を収穫する。この ような収穫と再生を何回も繰り返すことを可能にするため には，健全な，充実した株を養成することが重要である． そのため一般のニラの栽培では, 収穫開始前に長い株養成 期間を設けている.

刈り取りを繰り返す作物としては牧草があるが，冬作イ タリアンライグラスの場合, 刈り取り後 $5 \sim 10$ 日目までは 根株の貯蔵養分に依存しながら再生し, それ以後は独立栄 養状態となって根株に依存せずに再生する.ささらに, 葉の 再生に伴ら光合成能力の増加によって, 光合成産物の地下 部への蓄積が起こるが, 牧草の安定した収穫のためには, 再生による株の充実に十分な時間をかける必要があるとさ

2006 年 4 月 17 日 受付. 2006 年 8 月 11 日 受理.

* Corresponding author. E-mail: d.an@agri.pref.ibaraki.jp
れる（前田，1961）。ニラに颃いても，刚り取り後は新葉の 再生によって地下部貯蔵養分が消耗するが，しばらくする と再生した葉の成長に伴ら光合成能力の増加によって, 光 合成産物の地下部への蓄積が起こる（安・池田, 2006). こ の二つの過程がうまく両立することが，二ラを長期間にわ たって繰り返し収穫することを可能にする。 ニラの株養成 期間に株に貯蔵される養分は，その後の収量や品質に大き く影響する（木村，1991; 小松ら，1998）。 また，収穫回数の 増加は，翌年の収量低下につながる（Kim ら，1998）とされ るものの, ニラの刚り取り後の葉の再生時における貯蔵養 分の消耗や，再生してきた新しい葉の光合成によって作ら れた炭水化物などの動態については，注とんど調べられて いない.

著者らはこれまで, 株養成期および刈り取り後のニラの生 育は栽培時期によって異なり, 気温の影響を強く受けること を報告した（安・池田，2004a, b). 本報では，二ラの葉の刈 り取り時と, 刈り取り後の葉の再生時における各器官の重量 や糖類含量の変化を詳細に調査した結果を報告する. 


\section{材料および方法}

2001 年 8 月 28 日に, ニラ ‘グリーンベルト’を砂に播種 し, 60 日間育苗後, 砂耕装置 $($ 長さ $\times$ 幅 $\times$ 培地の深さ $=$ $1,160 \times 60 \times 10 \mathrm{~cm})$ に未分げつ苗 50 株を $20 \times 20 \mathrm{~cm}$ 間隔の 3 条植えで定植した. 定植後は散水型チューブ (エバフロー $\mathrm{S}$ 型）を利用した自動給液装置で, 1 日 3 回ずつ, 砂耕べッ ドの底面から排液が出るまで培養液を与えた。使用した培 養液は, 育苗時, 定植後とも, 大塚八ウス肥料 $\mathrm{A}$ 処方 $1 / 2$ 単位 $\left(\mathrm{N}: \mathrm{P}_{2} \mathrm{O}_{5}: \mathrm{K}_{2} \mathrm{O}: \mathrm{CaO}: \mathrm{MgO}=130: 60: 203: 115: 30 \mathrm{mg}\right.$ • $\left.\mathrm{L}^{-1}\right)$ とした.

栽培は大阪府立大学構内のビニルハウスで行った。栽培 期間中の低温期においては, 加温開始を $10^{\circ} \mathrm{C}$ 飞設定して, 電気温風器で八ウス内を加温した. 一方, 高温期には $28^{\circ} \mathrm{C}$ 以上で換気扇が作動するように設定し，9月までは八ウス 側面を開放した。

株を養成するため，定植後 5 か月間栽培を続け，2002 年 4 月 20 日に最初の地上部刈り取りを行った. 地上部は地面 から $3 \mathrm{~cm}$ のところを切った。 その後は約 25 日ごとに地上 部の刈り取りを行ったが, 解析に用いた株は 6 月 10 日に刈 り取ったものである.

刈り取り後の各器官の重量と糖類含量の変化を調べるた め, 刈り取り時と刈り取り後 4，8，12，16，20 日に，地下 部を含む株全体を 5 株ずつ採集し，根に付着している砂を よく洗い抢として, 葉, 鱗茎, 底盤抢よび根の 4 つの部分 に分け，調査に用いた。鱗茎は，底盤から刈り取り部分ま での $5 \mathrm{~cm}$ の部分とした.

各器官の糖類を調査するため, それぞれの試料 $5 \mathrm{~g}$ を 80 $\%$ \%エタール $50 \mathrm{~mL}$ で抽出した後, 減圧ろ過し,アルコー ル可溶物 (Alcohol Soluble Solid：ASS）とアルコール不溶 物（Alcohol Insoluble Solid：AIS）に分けて糖含量を定量し た. 各分析は, 同じ株を 3 回測定して平均值を用いて解析 した。

単糖類とスクロースの定量には, 示差屈折計を検出器と した高速液体クロマトグラフ（LC10A 型，島津製作所）を 用いた. カラムは NH2P-50 (昭和電工), カラム温度は $35^{\circ} \mathrm{C}$, 溶離液はアセトニトリル，流速は $0.8 \mathrm{ml} ・ \mathrm{~min}^{-1}$ とした。 ま たASS を塩酸で加水分解してから, ソモギ一ネルソン法を 用いてアルコール可溶性糖含量を測定した（上田，2000）. 減圧ろ過で残った AIS は, 過塩素酸を処理してから遠心分 離し，上澄及液の久を取り，フェノール硫酸法を用いて多 糖類含量を測定した（中村，1977；佐々木，1979）。

\section{結 果}

刈り取り時から刈り取り後20日目までの, 各器官におけ る分げつ当たりの乾物重と最大葉長を第 1 図に示した. 葉 は, 刈り取り後 12 日間は急速な伸長を示したが, 増加速度 はその後低下して，20日目には $43.8 \mathrm{~cm}$ となった。 葉の伸 長に伴い, 葉重は刈り取り後 20 日目に $0.4 \mathrm{~g}$ まで増加し続

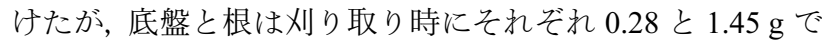
あったものがその後減り続け, 刈り取り後 20 日目にはそれ ぞれ 0.25 と $0.78 \mathrm{~g}$ となった。 また， $2.0 \mathrm{~g}$ あった全乾物重 は, 刈り取り後 12 日目には最子少ない $1.52 \mathrm{~g}$ まで減少した が, その後增加して刈り取り後 20 日目には $1.62 \mathrm{~g}$ となった.

各器官の ASS 全糖濃度を調べた結果 (第 2 図), 器官に よって濃度の推移は異なった。葉では刈り取り後 8 日目ま で増加し，その後減少したが，底盤では逆の増減パターン を示した. 鱗茎と根の ASS 全糖濃度は, 刈り取り後 4 日目 に一時的に低い值となり，その後増加してから大きな変化 は久られなかった。

第 3 図に，各器官に打ける ASS 全糖含量を示した．ASS 全糖含量は，刈り取り時には分げつ当たり $185 \mathrm{mg}$ あった が, 刈り取り後 4 日目には, 鱗茎と根で急激に減り, $107 \mathrm{mg}$ となった。 しかしその後, 葉と鱗茎に抢ける含量の増加に よって，刏り取り後 20 日目には分げつ当り $190 \mathrm{mg}$ まで増 加した. しかしこの時点でも, 鱗茎 + 底盤 + 根の ASS 全糖

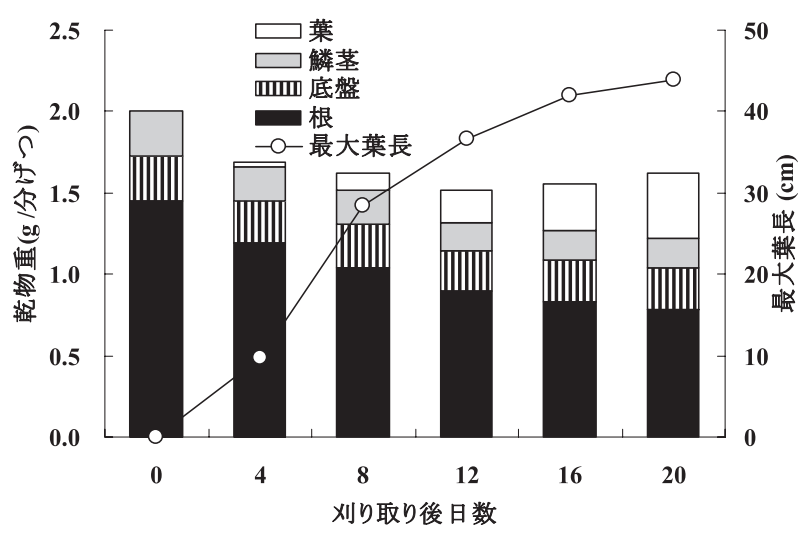

第 1 図 刈り取り後 20 日間の最大葉長および各器官の乾物重

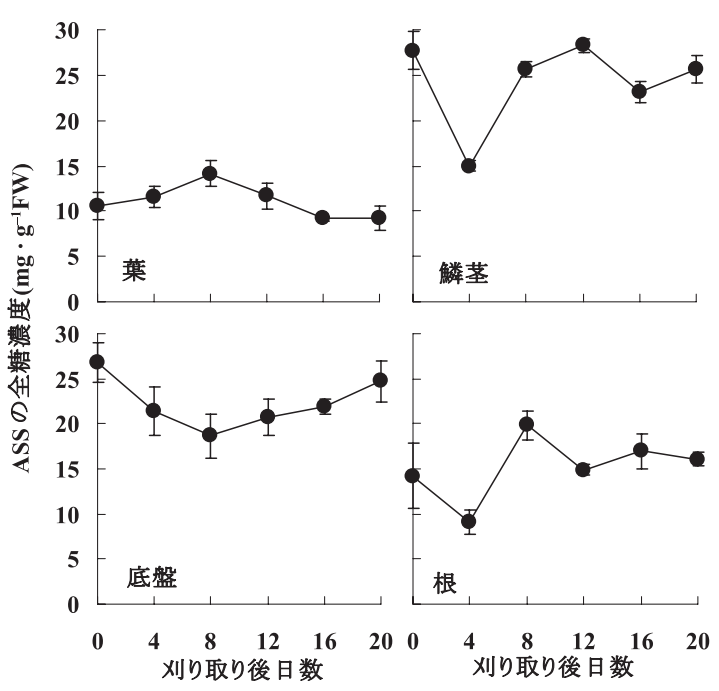

第 2 図 各器官における刈り取り後 20 日間の ASS の全糖濃度 の推移 図中の縦線は，標準誤差（n=5）を示す 


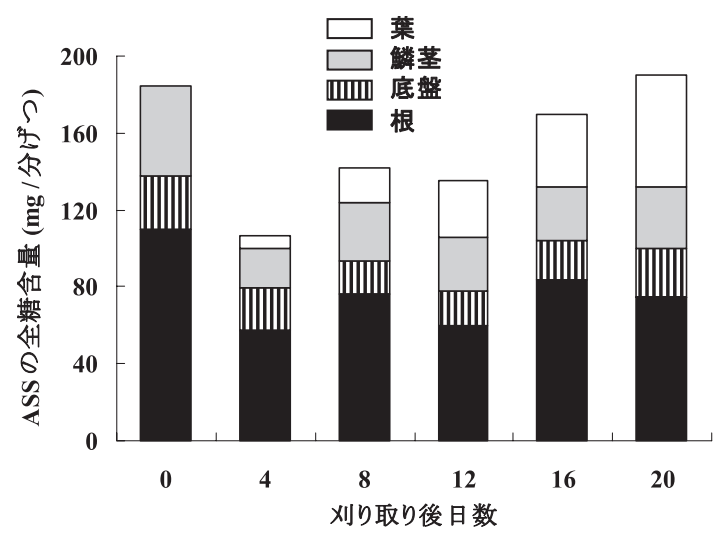

第 3 図 刈り取り後 20 日間の ASS の全糖含量

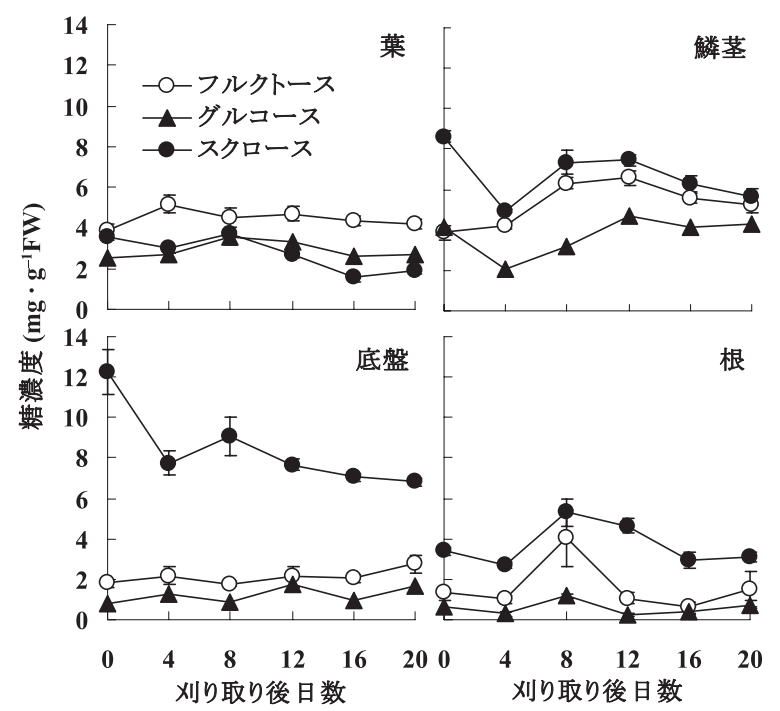

第 4 図 各器官における刈り取り後 20 日間の ASS 中フルク トース，グルコース，スクロースの濃度

図中の縦線は, 標準誤差 $(n=5)$ を示す

含量は $132 \mathrm{mg}$ 程度で，㺫り取り時の 71.4\%であった．ASS 全糖含量について，株全体に対する根の比率を見ると，刈 り取り時は 59.3\%で最も高かったが，その後減り続け，刈 り取り後 20 日目に最も低い39.2\%を示した.

ASS の分析により，糖としては主にグルコース，フルク トースおよびスクロースの 3 種類が検出された. 第 4 図に は, 刈り取り後 20 日間の, 各器官におけるこれら 3 種類の 糖濃度を示した。葉ではフルクトース濃度が最も高かった が，鱗茎，底盤打よび根ではスクロース濃度が最も高かっ た．特に底盤ではスクロース濃度が極めて高かった。濃度 の変化を見ると，葉では刈り取り後大きな変化はみられな かったが，鱗茎と底盤では，刚り取り後 4 日目にスクロー ス濃度が急激に低下した。特に鱗茎の場合，スクロースと グルコースが刚り取り時にはそれぞれ 8.62 と $4.13 \mathrm{mg} \cdot \mathrm{g}^{-1}$ であったが，刈り取り後 4 日目には 4.92 と $2.09 \mathrm{mg} \cdot \mathrm{g}^{-1}$ ま で低下し，その後増加する傾向を示した，根の場合，刈り

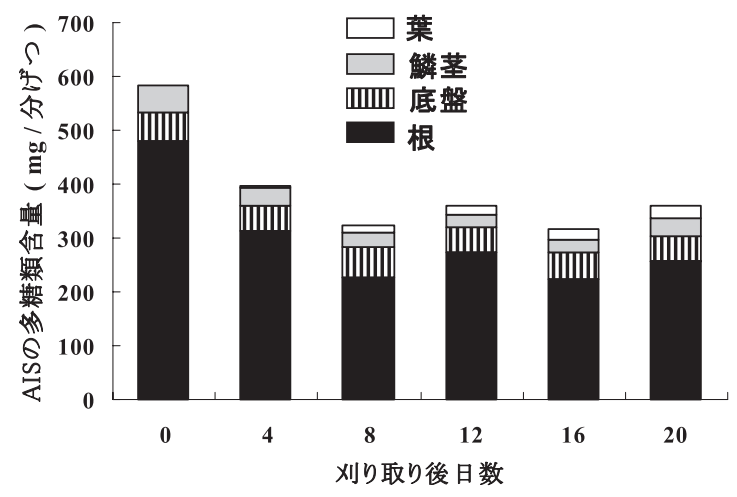

第 5 図 各器官に扎ける刈り取り後 20 日間のAIS の多糖類含量

取り時と刈り取り後 20 日目の糖濃度は同程度であったが, 刈り取り後 4 日から 8 日目にかけてスクロースとフルク トース濃度が一時的に増加する傾向が見られた。

第 5 図には，各器官の多糖類含量を示した，多糖類のほ とんどは，根と底盤に存在した。 これら器官の多糖類含量 の合計は，いずれの時期でも株全体の多糖類含量の $90 \%$ 前 後を占めた．特に根に打ける多糖類含量は多く，株全体の $70 \%$ 以上を占めていた。 全体量は，㺫り取り時に 1 分げつ 当たり $584 \mathrm{mg}$ あったが，その後減少し，刈り取り後 16 日 目に $316 \mathrm{mg}$ まで低下して, 20 日目には $360 \mathrm{mg}$ であった。

\section{考察}

刈り取り直後のニラ植物体は，地上部に打ける光合成能 が失われた状態であり, 葉の再生は, 残された器官に貯蔵 されていた栄養分と, 新しく吸収された養水分に依存する. 刈り取り後, 葉の再生によって地上部の重量は増加するが, 底盤や根の乾物重は, 刈り取り後 12 日目以降でも減少し続 けた.このことは，葉が伸長して光合成能力が増加してき た時点でも，根や底盤からの地上部への栄養供給が続いて いることを示している.

刈り取り後の ASS の全糖濃度や含量の著しい変化は, 葉 に打ける全糖濃度を維持するために鱗茎や根の糖が葉に転 流し，積極的に使用されていることを示している．特に， 刈り取り後 4 日目の鱗茎と根での ASS 全糖濃度の著しい低 下は，葉の急速な成長のためのエネルギ一源として使われ ているためであると考光られる。

Moorby（1970）はジャガイモで塊茎の急速な成長の際，他 の茎でエタノール不溶性 ${ }^{14} \mathrm{C} か ゙$ 著しく減少すると報告した.

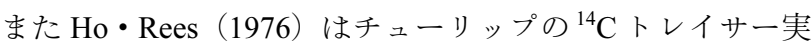
験で，再成長期と開花期にソース器官での澱粉や多糖類の 割合が急変するとしており, シンク能の高まりとソース器 官での急激な糖類の変化との関連性を示唆している。 ニ の場合も, 刈り取りによって再生する葉がシンクに変わり, その結果として鱗茎や根の糖濃度の急激な変化があったも のと思われる.

ASS の分析結果から，グルコース，フルクトース拈よび 
スクロースがニラの転流糖と考光られるが，特に鱗茎，底 盤拈よび根でスクロース濃度が高く，刈り取り直後飞急激 に低下寸ることから，主な転流糖はスクロースであると推 測できる.さらに，刈り取り後 4 日目に見られた鱗茎のグ ルコースとスクロース濃度の一時的低下は, 刈り取り後の 葉の急速な成長のために, 最も近い器官からこれら二種の 糖が供給されたためであると推測される。葉がまだ十分に 成長して抢らず光合成能力が十分でない刚り取り後 8 日目 の, 根に抢けるフルクトースとスクロースの一時的増加は, 刈り取り後に葉の急速な成長に伴って生じた鱗茎や根の糖 濃度の低下を補らために, 貯蔵養分としてのデンプンや多 糖類が分解した結果であるものと考兄られる。

一方, 各器官の AIS の多糖類含量の推移は, ASS 全糖と は異なるパターンを示した。特に底盤と根では糖類のほと んぞが AIS 多糖類であり，その含量は，刏り取り後著しく 減少したが, その減少は 8 日目から緩慢になった。

刈り取り後, 葉での ASS 全糖含量の増加が大きいこと と, その期間の AIS 多糖類含量の減少の推移からみて, 根 の AIS 多糖類が還元糖や重合度の低い糖に变化し, 葉へ転 流されたものと推察される。

同じユリ科植物であるアスパラガスでは, 根にフルクタ ンを蓄積する（日笠ら，1991; 金・崎山，1989）。ワケギの 場合は，葉鞘基部の主な成分は非構造性炭水化物であり， その主成分としてフルクトース，グルコース，スクロース および重合度が $3 \sim 10$ 程度のフラクタンが含まれているこ と, また，これらの糖は蓄積過程に扮いて重合度の高い糖 に変わること, などが報告されている（山崎ら，2001）。こ れらから推測すると, ニラでの AIS 多糖類の主な成分とし て,フルクタンやデンプンなぞ, 重合度の高い多糖類が考 えられる. Pollock（1984）は，一般にフルクタンを貯蔵糖 とする植物はスクロースが転流糖であるとして和り，本実 験の結果を裏付けしている.

安・池田（2006）は, ${ }^{13} \mathrm{C}$ 用い, ニラの刈り取り後同化 産物の転流を調べた結果, 刈り取り後はりん茎や根から ${ }^{13} \mathrm{C}$ の転流が多くなるが, 再生葉の同化能力の上昇によって, 貯蔵器官に対する依存度は低下寸ると報告した。しかし， 本実験でASS とAIS のすべての糖類を合計して見ると(第 6 図），刏り取り時には，1 分げつ当たり約 $770 \mathrm{mg}$ あった ものが, 刈り取り後 8 日目には約 $60 \%$ の $464 \mathrm{mg}$ まで減少 した. その後, 葉の成長に伴って増加し, 刈り取り後 20 日 目には約 $550 \mathrm{mg}$ まで回復した。刈り取り時には糖類すべ てが貯蔵されていたものと考光れば, 刈り取り後 8 日目ま でに約 40\%が消耗されたことになる。 また，刈り取り後 20 日目には，株全体では刈り取り時の約 72\%まで，地下部だ けでは約 $61 \%$ まで回復した. 刈り取り後の温度や日射, 養 水分管理などの外部要因によって程度は变わると考兄られ るが，本実験で調査した 20 日間だけでは，糖類含量の完 0 全な回復はみられなかった。すすねわち, 葉が收穫可能な大 きさになっても貯蔵器官への依存度は残っているため, す

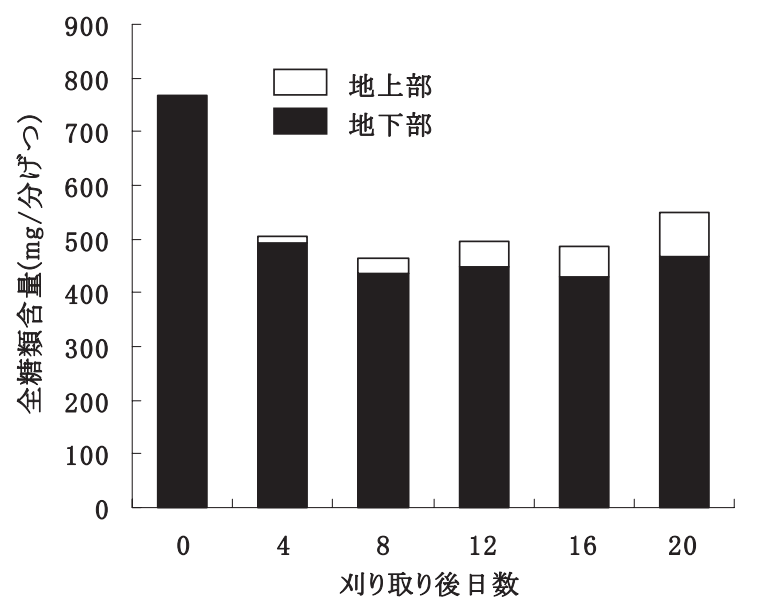

第 6 図 刈り取り後 20 日間の全糖類含量 全糖類含量はASS と AIS の全糖類含量の合計である 地下部は茎 + 底盤 + 根を示す

ぐ刈り取るならば，収穫を繰り返すことで，貯蔵養分の大 幅な減少を生じることになる。 ニラの収穫回数が多くなっ たり，花茎が伸びたりすることで収量が減少する（Kim ら， 1998）ことも，このような貯蔵養分の減少に上るものと考 光らる。

以上の上うに，ニラの刈り取り後の重量や糖類含量の変 化から, 鱗茎, 底盤拈よび根は, 葉の再生時に栄養を供給 するための栄養貯蔵器官であることが示された。特に, 乾 物重の変化から根は大きな栄養貯蔵器官で, 刈り取り後 20 日間以上にわたって地上部に栄養を供給し続けることが推 測できた。 また, 刈り取り後の葉の再生のために貯蔵器官 の貯蔵養分は葉に転流され, その結果として, 糖類含量が 著しく減少することが明らかにされた。一方，刈り取り後 16 日目以降になると, 糖類含量が増加に転ずることから, 葉の成長量が緩慢になり, 葉でのエネルギー要求の減少と 光合成産物の再蓄積が起こるものと考光られた，今後，本 実験で確認できた刈り取り後の糖の変化や各器官の役割の 結果を基に, 刈り取り前後の各器官での養分消耗や蓄積に ついて, 量的な観点からの検討が必要とされる.

\section{摘 要}

ニラの刈り取り後の生育特性や炭水化物の分配を詳細に 理解するために, 二ラを砂耕して, 葉, 底盤部, 鱗茎求よ び根に分け, 刈り取り後 20 日間の器官別の重量と糖含量の 変化を調べた。

植物体乾物重は刈り取り 12 日後まで減り続け, その後, 増加したが, 葉の長さが $40 \mathrm{~cm}$ 超えて刈り取り可能となっ た 20 日後でも，刚り取り時の $80 \%$ 程度であった，特に根 の乾物重は刈り取り後減少を続け, 20 日後には刈り取り時 の約 50\%になり，二ラの根は炭水化物の貯蔵器官としての 役割が大きいことが示された。

葉ではフルクトースが，その他の器官ではスクロースが 
多かった，スクロースは底盤部で特に多かったが，㺫り取 り4 日後にはいずれの器官でも濃度が大きく低下した。植 物体のアルコール可溶性糖含量は, 刈り取り 4 日後で最少 となり，その後，葉の伸長とともに増加して，刈り取り 20 日後には刈り取り時の含量を上回った。一方, 多糖類含量 は刈り取り8 日後まで減り続け，その後はあまり変化しな かった．植物体の全炭水化物（糖類）含量は刈り取り8 日 後に最少（刈り取り時の 60\%）となって，20日後でも刈り 取り時の $72 \%$ までしか回復しなかった。

\section{引用文献}

安 東赫・池田英男. 2004a. 播種時期を異にしたニラ （Allium tuberosum Rottler）“グリーンロード’の初期生 育特性. 園学雑. 73: 266-271.

安 東赫・池田英男. 2004b. 播種時期を異にした八ウス栽 培ニラ“グリーンロード’の収量と刈り取り後の再生 に及ぼす気温の影響. 農業施設. 34: 257-263.

安 東赫・池田英男. 2006 . ニラに打ける収穫前後の ${ }^{13} \mathrm{C}$ の吸収と転流. 園学雑. 75: 350-354.

日笠裕治・今田成雄・濱野 恵・長岡正昭. 1991. アスパ ラガス根部における糖含量と ${ }^{14} \mathrm{C}$ 光合成産物の分配. 園学雑. 60 (別 2) : 326-327.

Ho, L. C. and A. R. Rees. 1976. Remobilization and redistribution of reserves in the tulip in relation to new growth until anthesis. New Phytol. 76: 59-68.

Kim, C. K., K. B. Choi and J. Y. Oh. 1998. Yield of Chinese chive as affected by frequencies of leaf harvesting and flower stalk cutting. J. Kor. Soc. Hort. Sci. 39: 242-246.

金 永植・崎山亮三. 1989. アスパラガス貯蔵根に拈ける
発芽前後の糖の変化. 園学雑. 58: 383-390.

木村 栄. 1991. 秋冬どりニラに打ける保温時期, 収穫回数 が収量と養分含有量に及ぼす影響. 園学雑. 60 (別 1)： 334-335.

小松秀雄・前田幸二・榎本哲也. 1998. ニラの促成栽培に 扣ける ‘スーパーグリーンベルト’の播種扣よび定植 時期，栽植方法並びに株養成期間と生育，収量・品質. 高知農技七研報. 7: 97-104

前田 敏. 1961. 牧草の刈取りの生理生態学的研究. II. 冬 作イタリアンライグラスの刈取頻度による地上部再生 長と株・根の消耗. 日作紀. 30: 31-34.

Moorby, J. 1970. The production, storage, and translocation of carbohydrates in developing potato plants. Ann. Bot. 34: 297-308.

中村道徳. 1977. 澱粉の実験法と試験法一糖の定量法. p. 189. 澱粉科学ハンドブック。二国二郎ほか共著. 朝倉書店. 東京.

Pollock, C. J. 1984. Physiology and metabolism of sucrosylfructans. p. 97-114. In: D. H. Lewis (ed.). Storage carbohydrates in vascular plants. Cambridge Univ. Press, Cambridge.

佐々木 堯. 1979. 植物試料中の澱粉の定量一過塩素酸抽 出法. p. 5-6. 澱粉科学実験法. 鈴木繁男注か共著. 朝 倉書店. 東京.

上田悦範. 2000. 収穫物の評価と品質管理一化学成分の変 化. p. 134. 応用植物科学実験. 山口裕文注か共著. 養 賢堂. 東京.

山崎博子・西島隆明・腰岡政二・三浦周行．2001。 ワケギ の鱗茎の発達扣よび休眠状態の変化に伴う葉鞘基部に 抢ける炭水化物の動態. 園学雑. 70: 353-359. 